\title{
Catabolism of D-glucose by Pseudomonas putida U occurs via extracellular transformation into D-gluconic acid and induction of a specific gluconate transport system
}

\author{
Carmen Schleissner, Angel Reglero and José M. Luengo
}

Author for correspondence: José M. Luengo. Tel: +34 87 291226. Fax: +34 87 291226/291194.

Departamento de Bioquímica y Biología Molecular, Facultad de Veterinaria, Universidad de León, 24007 León, Spain

\begin{abstract}
Pseudomonas putida $U$ does not degrade $D$-glucose through the glycolytic pathway but requires (i) its oxidation to D-gluconic acid by a peripherally located constitutive glucose dehydrogenase (insensitive to osmotic shock), (ii) accumulation of D-gluconic acid in the extracellular medium, and (iii) the induction of a specific energy-dependent transport system responsible for the uptake of D-gluconic acid. This uptake system showed maximal rates of transport at $30^{\circ} \mathrm{C}$ in $50 \mathrm{mM}$ potassium phosphate buffer, pH 7.0. Under these conditions the $K_{m}$ calculated for D-gluconic acid was 6.7 $\mu \mathrm{M}$. Furthermore, a different transport system, specific for the uptake of glucose, was also identified. It is active and shows maximal uptake rates at $35^{\circ} \mathrm{C}$ in $50 \mathrm{mM}$ potassium phosphate buffer, pH 6.0, with a $K_{m}$ value of $8 \cdot 3 \mu \mathrm{M}$.
\end{abstract}

Keywords: D-glucose, D-gluconic acid, Pseudomonas putida

\section{INTRODUCTION}

The great catabolic versatility of bacteria included in the genus Pseudomonas has afforded these micro-organisms an important ecological advantage which has allowed them (i) to colonize new habitats, including those toxic for most micro-organisms, and (ii) to acquire and develop the specific mechanisms responsible for their natural resistance to harmful compounds (Bayly \& Wigmore, 1973; Collinsworth et al., 1973; Dagley, 1975; Dunn \& Gunsalus, 1973; Fuchs et al., 1994; Galli et al., 1992a; Gibson et al., 1970; Kobal et al., 1973; Lindow, 1992; Lunt \& Evans, 1970). In this respect, the appearance of a new catabolic pathway or the single presence of a specific enzyme involved in the catabolism of a particular compound, could account for the tremendous ecological adaptability shown by these bacteria, and also for the physiological differences among species of this genus and even among different strains of the same species (Galli et al., 1992b). However, although it has been shown that Pseudomonas can use many different molecules as carbon sources (Dagley,

Abbreviations: GOTS, D-gluconic-acid-specific transport system; GTS, glucose transport system; MM, minimal medium; PA, phenylacetic acid; PATS, PA transport system.
1975; Dunn \& Gunsalus, 1973; Galli et al., 1992b), some species of this genus are, paradoxically, unable to catabolize single compounds, such as sugars, that are usually degraded by most micro-organisms (MacGregor et al., 1992). This unusual behaviour could be due to the high catabolic specialization attained by these bacteria during the course of evolution. Adaptation to certain physicochemical or nutritional conditions permits Pseudomonas to survive in such media but, at the same time, the polarization of their catabolic pathways reduces their capacity to grow in other natural (or more common) conditions (Ramos \& Timmis, 1987).

We have previously shown that $P$. putida U can grow aerobically in a chemically defined medium containing phenylacetic acid (PA) as the sole carbon source (Martínez-Blanco et al., 1990b). Study of the assimilation of this compound revealed that its catabolism requires the induction of a PA transport system (PATS) which is strictly regulated by PA concentrations as well as by the presence of easily metabolizable sugars such as glucose (Martínez-Blanco et al., 1990a ; Schleissner et al., 1994). We also observed that the exhaustion of PA from cultures is considerably delayed when a preferentially used carbon source, such as D-glucose, is supplied to the medium. Moreover, we observed that glucose disappears from the medium some time before cellular 


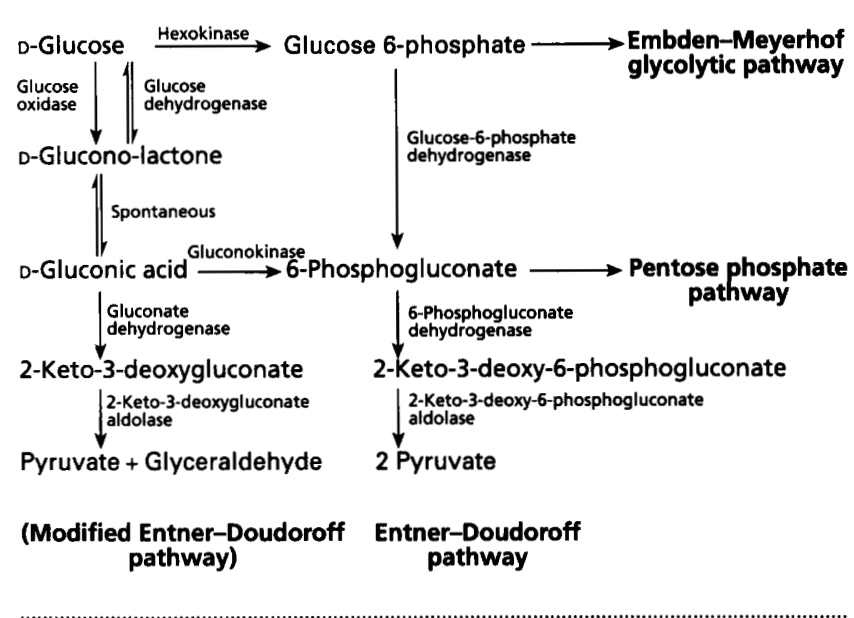

Fig. 1. Degradative pathways of D-gluconic acid.

growth starts. At least two different explanations could be advanced to explain this effect: (i) glucose might be accumulated as an intracellular reserve material (like poly-3-hydroxyalkanoates) (Anderson \& Dawes, 1990; Lageveen et al., 1988; Steinbüchel et al., 1992) before being catabolized, or (ii) glucose is transformed, as in other pseudomonads, into gluconic acid (Eisenberg et al., 1974; Lessie \& Phibbs, 1984; Ornston, 1971; Vicente \& Canovas, 1973; Whiting et al., 1976a, b) which remains in the culture broth and which would later be catabolized.

In this study, we studied both possibilities and analysed the metabolic circumstances which cause Pseudomonas putida to transform D-glucose into D-gluconic acid (Fig. 1). The ecological significance of such catabolic behaviour is also discussed.

\section{METHODS}

Materials. D-Gluconic acid, D-glucose, D-galactose, D-fructose, D- and L-arabinose, D-mannose, ATP, CoA, dithiothreitol (DTT), streptomycin sulfate, chloramphenicol, kanamycin sulfate and hexokinase type $\mathrm{X}$ from bovine heart were obtained from Sigma. NAD, NADP and D-gluconic acid assay kits were purchased from Boehringer. L-[U- $\left.{ }^{14} \mathrm{C}\right]$ leucine [351 $\left.\mathrm{mCi}(13 \mathrm{GBq}) \mathrm{mmol}^{-1}\right]$ and $\mathrm{D}-\left[\mathrm{U}-{ }^{14} \mathrm{C}\right] \mathrm{glucose}[293 \mathrm{mCi}$ $(10.8 \mathrm{GBq}) \mathrm{mmol}^{-1}$ ] were from Amersham. 2- and 4-Nitrophenol, $\mathrm{NaF}$ and $\mathrm{NaN}_{3}$ were obtained from Merck. All other products were of analytical quality or HPLC grade.

Strain. P. putida (strain U) used in this work was from our collection. The strain was originally obtained from Professor R. A. Cooper (Department of Biochemistry, University of Leicester, UK).

Culture media and growth conditions. P. putida U was maintained on Trypticase soy agar (TSA, Difco) as reported previously (Martínez-Blanco et al., 1990b) and growth slants $\left(8 \mathrm{~h}\right.$ at $\left.30^{\circ} \mathrm{C}\right)$ were used to inoculate liquid medium. Each $2000 \mathrm{ml}$ Erlenmeyer flask containing $250 \mathrm{ml}$ of the required medium (see below) was inoculated with $5 \mathrm{ml}$ of a bacterial suspension $\left(10^{10}\right.$ bacteria). Incubations were carried out as indicated previously (Martínez-Blanco et al., 1990b). The minimal medium (MM) used for growth of $P$. putida was a chemically defined one containing different salts and PA as the sole carbon source (MM+PA) (Martínez-Blanco et al., 1990a). When required, an additional carbon source was supplied to the medium or PA was replaced by a different one. Bacterial growth was measured spectrophotometrically at $540 \mathrm{~nm}$.

Enzymic assays. Cell-free extracts of $P$. putida U were obtained as described previously (Martínez-Blanco et al., 1990b). The hexokinase, glucose-6-phosphate isomerase, glucose dehydrogenase and 6-phosphofructokinase activities in cell-free extracts were determined using the methods of Bergmeyer (1974a, c), King (1974) and Strecker (1955). Glucose dehydrogenase activity was studied in membrane preparations obtained as previously reported for similar or for other membrane-bound enzymes (Ortiz et al., 1989; Rodríguez-Aparicio et al., 1988; Troy et al., 1982).

Analytical determinations. Residual D-glucose was measured by the glucose oxidase test (Keston, 1956). PA assimilation by P. putida was monitored by HPLC (Schleissner et al., 1994). Protein determination was carried out by the method of Bradford (1976) and D-gluconic acid was evaluated by the gluconate kinase test (Bergmeyer, 1974b).

Measurement of $\mathrm{D}-\left[\mathrm{U}-{ }^{14} \mathrm{C}\right]$ glucose and $\mathrm{D}-\left[\mathrm{U}-{ }^{14} \mathrm{C}\right]$ gluconic acid uptake rates. Bacteria were cultured for $16 \mathrm{~h}$ in $\mathrm{MM}+\mathrm{PA}$ until PA was exhausted, then D-glucose $(10 \mathrm{mM})$ was supplied to the cultures. Cells were harvested at different times, washed twice with sterile distilled water and resuspended in $50 \mathrm{mM}$ potassium phosphate buffer, $\mathrm{pH} 6$ (for glucose uptake) or $\mathrm{pH} 7$ (for D-gluconic acid uptake). Aliquots of $1.5 \mathrm{ml}\left(1.5 \times 10^{9}\right.$ bacteria) were placed in $25 \mathrm{ml}$ Erlenmeyer flasks and preincubated at $30^{\circ} \mathrm{C}$ for $30 \mathrm{~min}$ in a thermostatically controlled bath at 160 strokes per min before glucose $(18.6 \mu \mathrm{M}$ unlabelled glucose $+0 \cdot 103 \mu \mathrm{M}\left[\mathrm{U}_{-}{ }^{14} \mathrm{C}\right]$ glucose, $10^{5}$ c.p.m.) or gluconic acid $(114 \mu \mathrm{M}$ unlabelled gluconic acid $+0.103 \mu \mathrm{M}$ D[U- $\left.{ }^{14} \mathrm{C}\right]$ gluconic acid, $10^{5}$ c.p.m.) was added. Incubations were carried out for different periods (usually $1 \mathrm{~min}$ ), halted by the addition of 10 vols of a cold aqueous solution of unlabelled Dglucose or D-gluconic acid at the same concentration as indicated above, rapidly filtered through Millipore filters (pore size $0.45 \mu \mathrm{m}$ ) and washed with $2 \times 10 \mathrm{ml}$ sterile distilled water. All the washing process was carried out in $20 \mathrm{~s}$. The filters were dissolved in $10 \mathrm{ml}$ scintillation fluid and the radioactivity measured as reported elsewhere (Bergmeyer, 1974b; Schleissner et al., 1994). D-Glucose and D-gluconic acid uptake rates are given as $\mathrm{pmol} \mathrm{min}^{-1}$.

Study of different inhibitors on the two uptake systems was performed by the addition of the inhibitor at the required concentration (usually $1 \mathrm{mM}$ ) to the uptake mixture 2 min before substrate addition.

Protein synthesis. Protein synthesis was measured by following the incorporation of $\mathrm{L}-\left[\mathrm{U}-{ }^{14} \mathrm{C}\right]$ leucine into trichloroacetic acid (TCA)-insoluble material as reported previously (Luengo et al., 1980). When required, protein synthesis was stopped by adding chloramphenicol, streptomycin or kanamycin to the bacterial cultures. In all cases, the concentration of antibiotic was $75 \mu \mathrm{g} \mathrm{ml}^{-1}$. Although in some experiments all three antibiotics were employed separately, chloramphenicol was routinely used. Under these conditions, $\mathrm{L}_{-}\left[\mathrm{U}^{14} \mathrm{C}\right]$ leucine ceased to be incorporated into protein $15 \mathrm{~min}$ after adding the required antibiotic. 
Identification and purification of D-gluconic acid from cultures of $\boldsymbol{P}$. putida. D-Gluconic acid was isolated from cultures of $P$. putida $\mathrm{U}$ as follows. Bacteria were grown in two Erlenmeyer flasks for $16 \mathrm{~h}\left(\mathrm{OD}_{540} 3 \cdot 4 ; 3 \cdot 4 \times 10^{9}\right.$ bacteria ml $\left.{ }^{-1}\right)$ in $\mathrm{MM}+\mathrm{PA}$ after which they were centrifuged $(10000 \mathrm{~g}$, $10 \mathrm{~min}, 2^{\circ} \mathrm{C}$ ), washed twice with sterile distilled water to eliminate the residual medium and resuspended in $500 \mathrm{ml}$ of a solution of D-glucose $(10 \mathrm{mM})$ in sterile distilled water. The culture was incubated in an orbital shaker at $30^{\circ} \mathrm{C}(200$ r.p.m.) and the $\mathrm{pH}$ was automatically kept at $7 \cdot 0$ by continuously adding $\mathrm{KOH}(0 \cdot 1 \mathrm{M})$. Residual D-glucose was measured at intervals and, when all the sugar had been exhausted, the cultures were centrifuged as above. The pellet was discarded and the clear supernatant was filtered through Millipore filters $(0.45 \mu \mathrm{m}$ pore size). The final volume $(450 \mathrm{ml})$ was frozen $\left(-40^{\circ} \mathrm{C}\right)$ and lyophilized. The solid obtained $(905 \mathrm{mg})$ was dissolved in $30 \mathrm{ml}$ distilled water and centrifuged again to eliminate insoluble materials. The supernatants $(28 \mathrm{ml})$ were dialysed against 1 litre sterile distilled water overnight at $4{ }^{\circ} \mathrm{C}$. This procedure was repeated and the dialysed volumes were mixed, frozen and lyophilized. The purified product was analysed by IR, thin-layer chromatography (TLC) and NMR (see below).

TLC was performed using silica-gel plates. The mobile phase was butanol/acetic acid/water (2:1:1, by vol.). The spots of $\mathrm{D}$-glucose and D-gluconic acid were developed by spraying the plates with a solution containing $0.5 \mathrm{~g}$ potassium permanganate in $100 \mathrm{ml} \mathrm{NaOH}$. The $R_{F}$ values of D-glucose and Dgluconic acid were 0.37 and 0.27 , respectively.

NMR spectral analyses were recorded at $300\left({ }^{1} \mathrm{H}\right)$ and $75\left({ }^{13} \mathrm{C}\right)$ $\mathrm{MHz}$ on a Varian Unity 300 Spectrometer. Spectra were measured in $\mathrm{D}_{2} \mathrm{O}$ with an without trace amounts of $\mathrm{CD}_{3} \mathrm{OD}$.

Enzymic synthesis of labelled D-gluconic acid. D-[U$\left.{ }^{14} \mathrm{C}\right]$ Gluconic acid was obtained enzymically from $\mathrm{D}-[\mathrm{U}-$ ${ }^{14} \mathrm{C}$ glucose. The procedure used was as follows: $100 \mu \mathrm{Ci}$ (3.7 MBq) $\mathrm{D}-\left[\mathrm{U}-{ }^{14} \mathrm{C}\right]$ glucose was incubated in potassium phosphate buffer $(50 \mathrm{mM}, \mathrm{pH} 7)$ with glucose oxidase (Boehringer) for $1 \mathrm{~h}$ at $25^{\circ} \mathrm{C}$. The transformation of $\mathrm{D}$-[U${ }^{14}$ Clglucose into labelled D-gluconic acid was followed by TLC analysis. The spots corresponding to gluconic acid were scraped from the plates, resuspended in scintillation fluid and the radioactivity measured. With this procedure we obtained a transformation yield greater than $96 \%$. This labelled Dgluconic acid was used for different experiments.

Cell-shocking procedure. Osmotic shock was carried out by the method reported by Neu \& Heppel (1965), slightly modified by us (Rodríguez-Aparicio et al., 1987).

\section{RESULTS AND DISCUSSION}

Pseudomonas putida $\mathrm{U}$ is able to grow aerobically in a chemically defined medium containing PA as the sole carbon source (Martínez-Blanco et al., 1990b). We have previously shown that PA catabolism in this bacterium is achieved through a new catabolic pathway which involves the participation of a specific PATS (Schleissner et al., 1994) as well as a phenylacetyl-CoA ligase (PCL) (Martínez-Blanco et al., 1990b), which catalyses the first reaction of this unknown catabolic route. Study of PA assimilation showed that this aromatic compound is not catabolized in the presence of D-glucose until this sugar has been exhausted from the broth (Schleissner et al., 1994). However, it can be observed that although

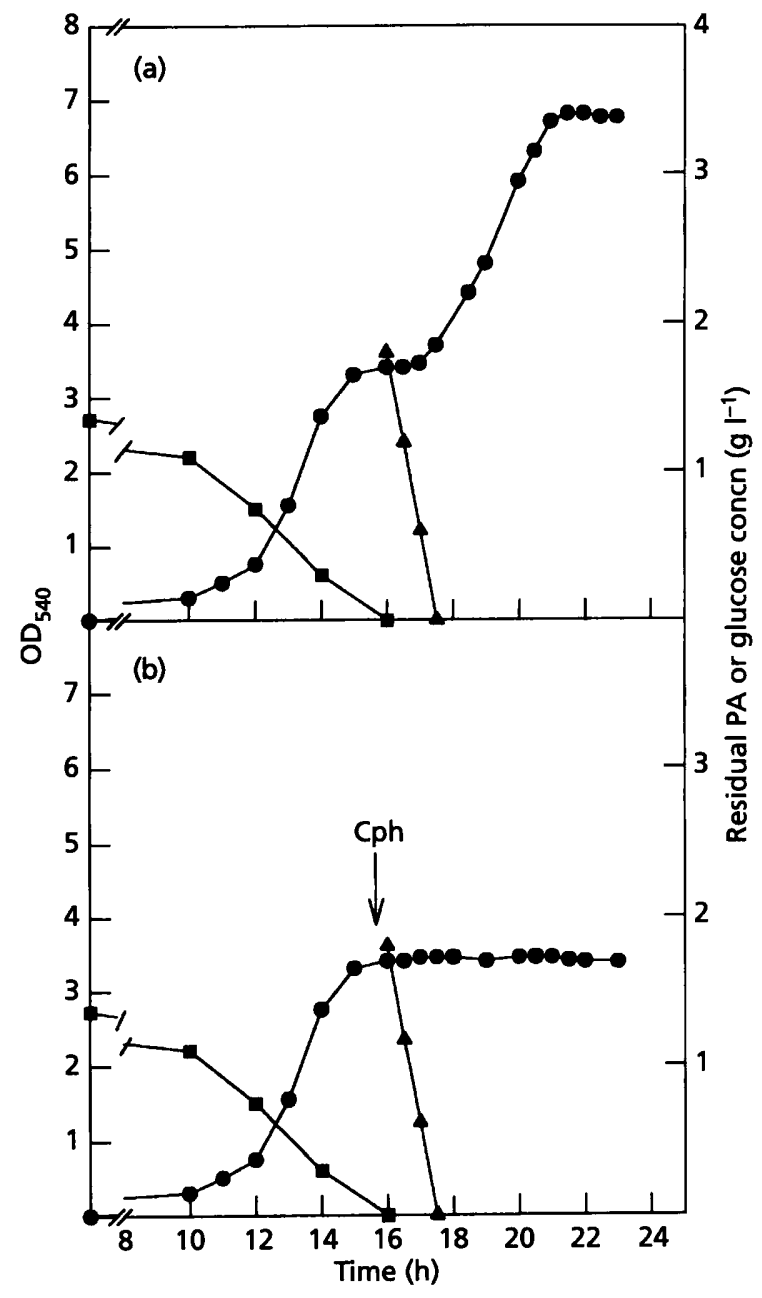

Fig. 2. Disappearance of $D-g l u c o s e$ from bacterial cultures. $P$. putida $U$ was grown for $16 \mathrm{~h}$ in $\mathrm{MM}+\mathrm{PA}(10 \mathrm{mM})$ and then (a) glucose $(10 \mathrm{mM})$ or (b) glucose $(10 \mathrm{mM})+$ chloramphenicol $\left(75 \mu \mathrm{g} \mathrm{ml}^{-1}\right)(\mathrm{Cph})$ were added. Results are the mean of three different assays. O, Bacterial growth and $\boldsymbol{\Lambda}$, residual D-glucose or $\mathbf{D}, \mathrm{PA}$.

glucose disappears from the cultures, exponential growth does not start until glucose has been almost exhausted (Schleissner et al., 1994). These results suggest that (i) glucose must be transformed into a different compound before being incorporated by the bacteria, or (ii) glucose is taken up by the cells and stored as a reserve compound for later use as a carbon source.

To clarify which of these two possibilities is in fact used by $P$. putida $\mathrm{U}$, we performed the following sets of experiments. We first studied the consumption of $\mathrm{D}$ glucose, together with bacterial growth, in cultures of $P$. putida grown for $16 \mathrm{~h}$ in MM containing PA as the sole carbon source and to which $10 \mathrm{mM}$ glucose was supplied when all PA had been exhausted (Fig. 2). It can be observed that glucose (evaluated by the glucose oxidase test) was depleted very quickly from the broth even 


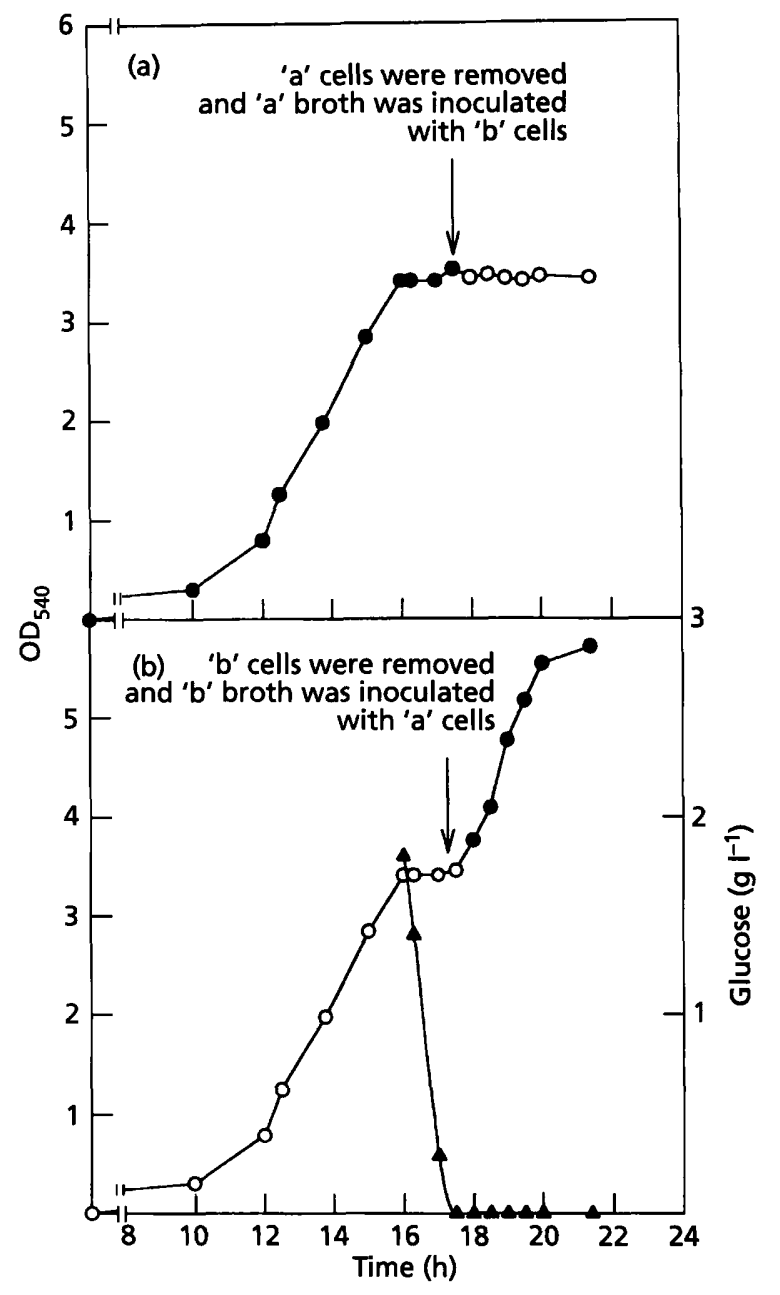

Fig. 3. Extracellular transformation of D-glucose. P. putida $U$ was grown in $\mathrm{MM}+\mathrm{PA}(10 \mathrm{mM})$ for $16 \mathrm{~h}(0,0)$. At this time glucose $(10 \mathrm{mM})(\boldsymbol{A})$ was added to the culture designated ' $b$ '. After $1 \mathrm{~h}$, cells from cultures ' $a$ ' and ' $b$ ' were removed by centrifugation and those from ' $a$ ' were inoculated into broth ' $b$ ' and vice versa. Results are the mean of three different assays.

though protein synthesis had been stopped with chloramphenicol (Fig. 2b). Similar results were obtained when streptomycin or kanamycin were used as inhibitors (data not shown). These results indicated that D-glucose was being transformed into a different molecule which is not a substrate of glucose oxidase and that the enzyme or enzyme system required for this conversion was present in the cells (since de novo synthesis of proteins was not required). However, these data did not clarify whether glucose was transformed outside the cell or intracellularly.

We therefore performed the experiment indicated in Fig. 3 . Cells were grown in the same conditions $(16 \mathrm{~h}$ in $\mathrm{MM}+\mathrm{PA}$ ) and then $10 \mathrm{mM}$ glucose was added to the Erlenmeyer flask designated ' $b$ ' (Fig. 3b), whereas no addition was made to a similar one designated ' a' (Fig.

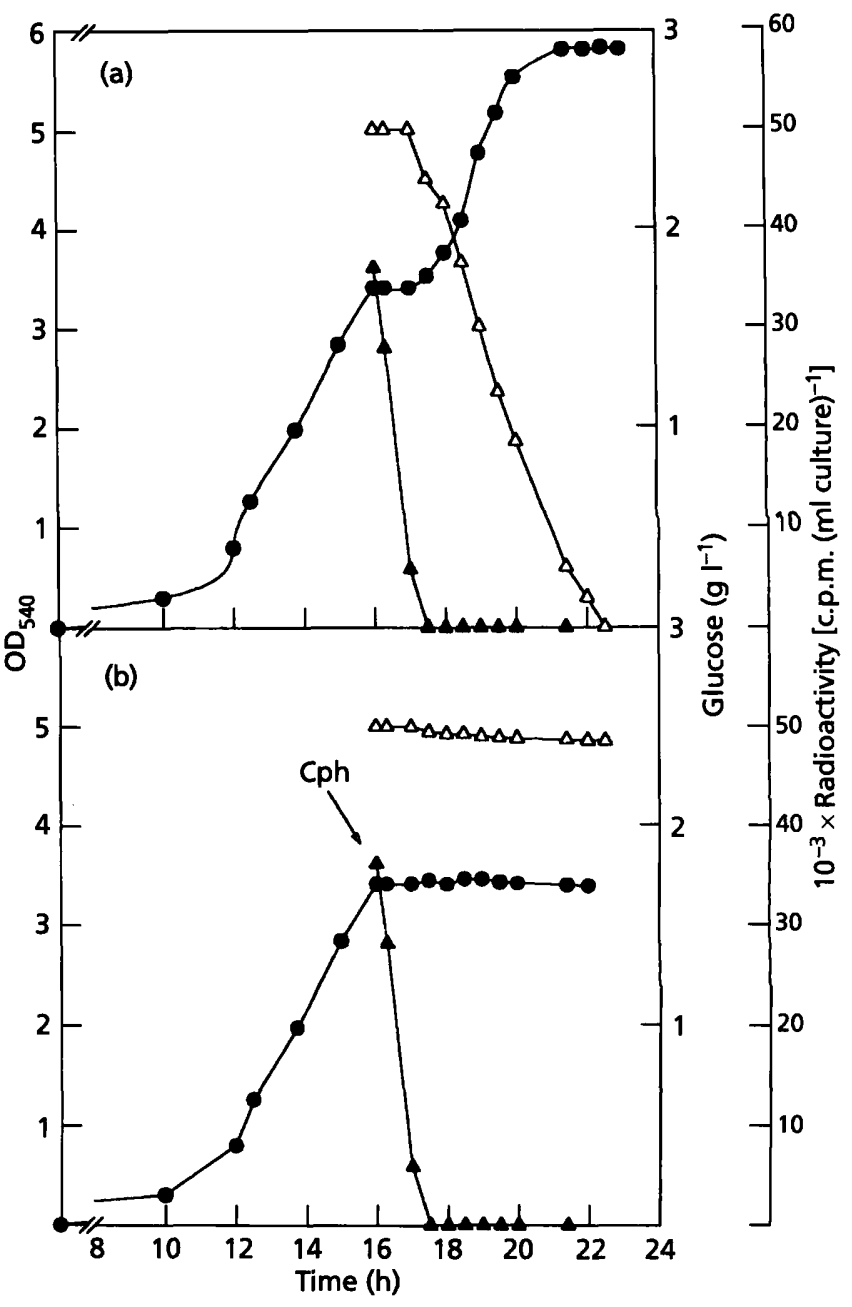

Fig. 4. Bacterial growth and disappearance of $D-\left[U-{ }^{14} C\right]$ glucose. $P$. putida $U$ was grown in $M M+P A(10 \mathrm{mM})$ for $16 \mathrm{~h}(\mathrm{D}-\mathrm{k})$. At this time: (a) $D-\left[U-{ }^{14} \mathrm{C}\right] g$ lucose or (b) D-[U${ }^{14} \mathrm{C}$ glucose + chloramphenicol $\left(75 \mu \mathrm{g} \mathrm{ml}^{-1}\right)$ (Cph) were added. $\Delta$, Residual $D$-glucose and $\Delta$, radioactivity in the culture broth. Results are the mean of three different assays.

3a). The cultures were incubated for $1 \mathrm{~h}$ and were then centrifuged and resuspended as follows: cells from Erlenmeyer flask ' $a$ ' were inoculated into the culture broth obtained from Erlenmeyer flask ' $b$ ', while cells from Erlenmeyer flask ' $b$ ' were inoculated into the broth obtained from Erlenmeyer flask ' $a$ '. Fig. 3 indicates that cellular growth was only observed in the culture broth to which glucose had been added (Fig. 3b), indicating that (i) cells did not accumulate D-glucose intracellularly, and (ii) glucose was transformed by the cells into a different compound that remained in the broth until it began to be catabolized.

To further analyse this effect and to establish the nature of the compound accumulated, $10 \mathrm{mM}$ D-glucose and D-[U- $\left.{ }^{14} \mathrm{C}\right]$ glucose $(100 \mu \mathrm{Ci})$ were added to a bacterial culture grown for $16 \mathrm{~h}$ in the same medium and conditions as above. Fig. 4(a) shows that whereas 
glucose (evaluated by glucose oxidase) disappeared from the medium, the radioactivity remained in it over the first hour. Later, when the bacteria started to grow, the labelled material also disappeared. However, when chloramphenicol was added to the culture before glucose had been supplied, glucose disappeared but the radioactivity remained in the culture as a consequence of the lack of cellular growth (Fig. 4b). These data lend further support to the above results and strongly suggest that glucose is transformed extracellularly into a different compound which requires some time to be catabolized.

This molecule was purified from the broths and studied. TLC analysis revealed that the labelled compound derived from D-[U- $\left.{ }^{14} \mathrm{C}\right]$ glucose has the same $R_{F}$ as $\mathrm{D}-$ gluconic acid $(0 \cdot 27)$. Furthermore, purification of the molecule accumulated when an aqueous solution of unlabelled D-glucose (see Methods) was incubated with $P$. putida, permitted the analysis of the product by NMR. The spectral data obtained were identical to those of a standard of D-gluconic acid as well as to those reported by different authors (Bendall et al., 1982; Bock \& Pedersen, 1983; Milson \& Meers, 1985; Tsai et al., 1995). These data unequivocally demonstrate that in $P$. putida $\mathrm{U}$, as in other pseudomonads (Lessie \& Phibbs, 1984 ), the catabolism of D-glucose requires previous oxidation of this sugar to D-gluconic acid (pentahydroxycaproic acid).

Fig. 4 suggests that assimilation of D-gluconic acid did not start immediately it was produced since bacterial growth was not observed immediately (Fig. 4a). This interval (about $1 \mathrm{~h}$ ) corresponds to the time required for all the glucose to be eliminated from the medium (see Figs 2-4). It could be speculated that D-glucose could inhibit the degradation of D-gluconic acid and for this reason this compound is not catabolized until the sugar has been completely eliminated from the broth. This assumption is reasonably consistent with the hypotheses proposed by different authors (Kheshghi et al., 1954; Milson \& Meers, 1985; Stubbs et al., 1940). However, it is also possible that this delay might be due to the necessity for induction of certain enzymic steps required for the catabolism of D-gluconic acid. To test which of these two possibilities is true, we measured the transformation of D-glucose into D-gluconic acid when different quantities of sugar $(10$ and $30 \mathrm{mM})$ were added to the bacterial cultures. Fig. 5 shows that, whereas in the presence of $10 \mathrm{mM}$ glucose the catabolism of $\mathrm{D}$ gluconic acid did not start until the glucose had been eliminated, in the presence of $30 \mathrm{mM}$ glucose (Fig. $5 \mathrm{~b}$ ) the utilization of this acid started before all the glucose had been transformed. These experiments showed that the delay observed was due to the time required for the induction of the proteins involved in the catabolism of the acid and allowed us to conclude that, at least under the conditions reported here, D-glucose does not inhibit the catabolism of D-gluconic acid.

Study of the first step in the degradation of D-glucose via D-gluconic acid by $P$. putida $\mathrm{U}$ revealed that two different enzymes, or enzyme systems, are involved: a dehydro-

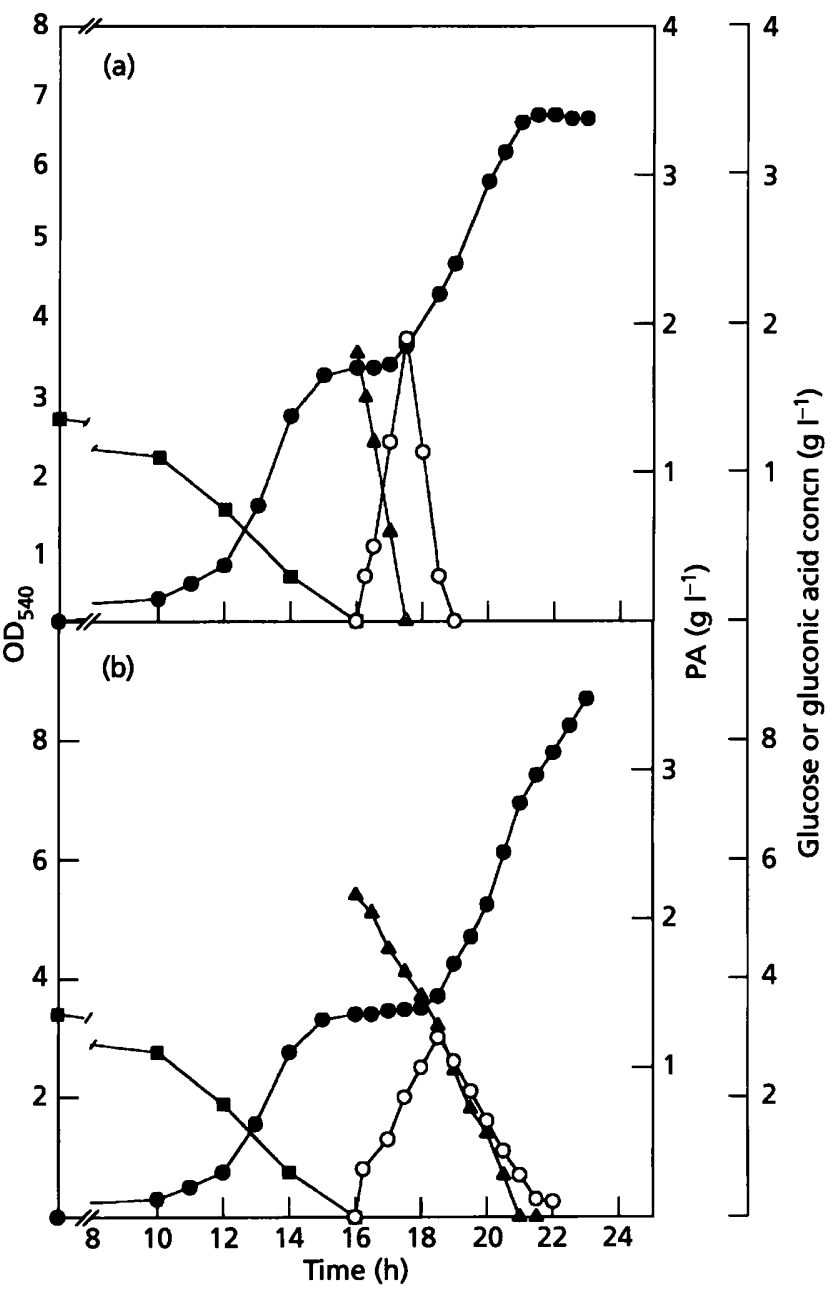

Fig. 5. Appearance and consumption of D-gluconic acid when $P$. putida $U$ was grown in MM+PA ( $\square$ ) for $16 \mathrm{~h}$ and then $10 \mathrm{mM}$ (a) or $30 \mathrm{mM}$ (b) D-glucose were added. Bacterial growth; $\Delta$, glucose consumption; $O$, gluconic acid formation. Results are the mean of three different assays.

genase and a D-gluconic-acid-specific transport system (GOTS). We observed that whereas the GOTS was inducible (see below), the protein responsible for the oxidation of D-glucose to D-gluconic acid was a membrane-bound constitutive enzyme (Ciucu \& Patroescu, 1984) not sensitive to osmotic shock (RodriguezAparicio et al., 1987) (data not shown). In other pseudomonads (P. Aluorescens and P. ovalis) the oxidation of $\mathrm{D}$-glucose is carried out by $\mathrm{NAD}(\mathrm{P})$-glucose dehydrogenases (Hauge, 1966; Jermyn, 1960; Milson \& Meers, 1985; Wood \& Schwert, 1953). In filamentous fungi (Aspergillus and Penicillium) the formation of $\mathrm{D}$ gluconic acid is also catalysed by a glucose dehydrogenase (Milson \& Meers, 1985; Van Dijken \& Veenhuis, 1980). This enzyme is located at the cell surface (Witteveen et al., 1990), intracellularly in peroxisomes (Van Dijken \& Veenhuis, 1980) and also, in some cases and probably as a consequence of mycelial lysis, free in the culture broth (Petruccioli et al., 1993). 


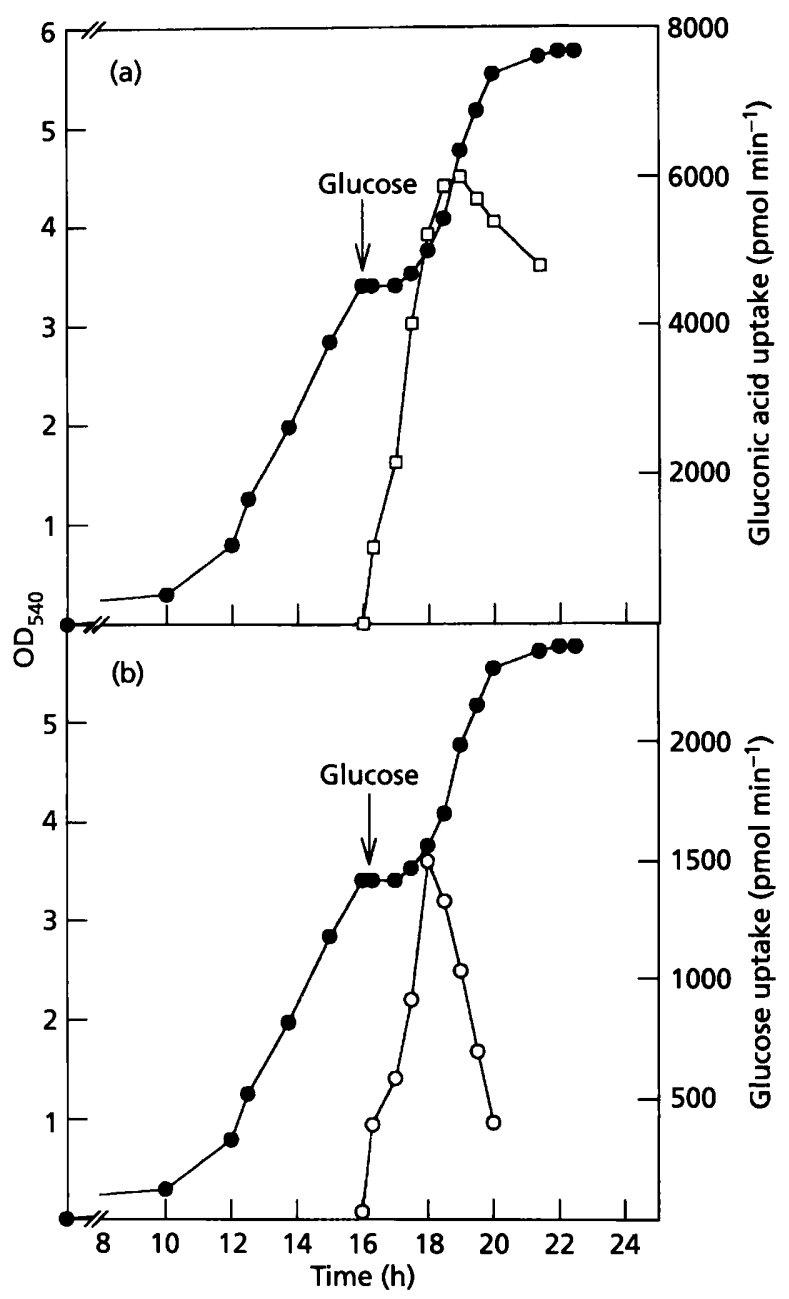

Fig. 6. D-Gluconic acid and D-glucose transport systems. Appearance of (a) D-gluconic acid transport system (GOTS, $\square$ ) and (b) D-glucose transport system (GTS, O) when $P$. putida $U$ was grown (O) in $\mathrm{MM}+\mathrm{PA}(10 \mathrm{mM})$ for $16 \mathrm{~h}$ and later glucose $(10 \mathrm{mM})$ was added. Results are the mean of three different assays.

Fig. 6 shows that cells grown in $\mathrm{MM}+\mathrm{PA}$ are not able to transport any D-gluconic acid. However, when glucose was added, gluconic acid was produced and the GOTS appeared. Similar results were obtained when Dgluconic acid was directly added to the cultures (not shown). Study of this uptake indicated that it is an energy-dependent process which is inhibited by 2- and 4nitrophenol and KCN whereas it is not inhibited by up to $10 \mathrm{mM}$ arsenate (to study the effect of arsenate, potassium phosphate buffer was replaced by water adjusted to $\mathrm{pH} 7$ ). These results suggest that ATP is not the energy source for this active transport system (Table 1) and it could be surmised that the energy for the GOTS is derived only from the electron transport system. Similar results have been reported in this strain for the PATS (Schleissner et al., 1994). Maximal uptake rats were achieved at $30^{\circ} \mathrm{C}$ in $50 \mathrm{mM}$ potassium phosphate buffer, $\mathrm{pH}$. Under these conditions the $K_{\mathrm{m}}$ for D-gluconic acid was $67 \mu \mathrm{M}$ and the $V_{\max }$ was
Table 1. D-Gluconic acid uptake by $P$. putida when incubated in the presence of different energy inhibitors

Uptake is expressed as a percentage of the uptake in the control incubation $(100 \%)$ which corresponds to $6000 \mathrm{pmol} \mathrm{min}^{-1}$. The

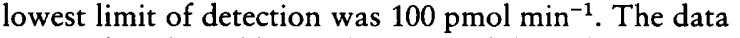
reported in this table are the mean of three different assays.

\begin{tabular}{|lccc|}
\hline Inhibitor & \multicolumn{2}{c|}{ D-Gluconic acid uptake (\%) } \\
\cline { 2 - 4 } & $\mathbf{1} \mathbf{m M}^{*}$ & $\mathbf{1 0 0} \boldsymbol{\mu} \mathbf{M}^{*}$ & $\mathbf{1 0} \boldsymbol{\mu} \mathbf{M}^{*}$ \\
\hline Control (none) & 100 & & \\
Potassium arsenate & 100 & & \\
2-Nitrophenol & 18 & 40 & \\
4-Nitrophenol & 5 & 27 & 50 \\
Sodium azide & 63 & & \\
Potassium cyanide & 2 & 10 & 46 \\
Sodium fluoride & 88 & & \\
$N, N^{\prime}$-Dicyclohexylcarbodiimide & 100 & & \\
\hline
\end{tabular}

* Final concentration of the inhibitor in the assay.

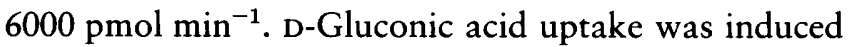
by D-gluconic acid but not by other similar compounds, TCA intermediates or sugars. Furthermore, the GOTS was not inhibited by D-glucose even when this sugar was added to the uptake mixture at $5 \mathrm{mM}$.

Study of the catabolic pathway followed by P. putida $U$ in the degradation of D-gluconic acid (see Fig. 1) was approached by testing the ability of this bacterium to grow in minimal media containing different carbon sources. We observed that $P$. putida $\mathrm{U}$ was not able to catabolize D-glucose by the glycolytic pathway since labelled D-glucose was not directly incorporated by the cells (see Fig. 4). Furthermore, this bacterium was not able to use D-mannose, D-galactose, D-pseudoheptulose, $\mathrm{D}$-xylose or D- and L-arabinose as the sole carbon source, neither did it degrade disaccharides such as lactose, maltose and sucrose, whereas it did grow slowly in MM containing D-fructose. The fact that $P$. putida $\mathrm{U}$ was able to catabolize fructose but not glucose suggests either that in the glycolytic pathway a block exists in the glucose uptake system, in the hexokinase or in the reaction catalysed by glucose-6-phosphate isomerase or, alternatively, that fructose is not catabolized by the glycolytic pathway.

We studied these two possibilities and found that once glucose had been added to cultures, a glucose transport system (GTS) was induced (see Fig. 6b). This uptake occurs through an active transport system (Table 2) which shows maximal uptake rates at $35^{\circ} \mathrm{C}$ in $50 \mathrm{mM}$ potassium phosphate buffer, $\mathrm{pH} 6$. Under these conditions, the $K_{m}$ and $V_{\max }$ values were $8.3 \mu \mathrm{M}$ and $1500 \mathrm{pmol} \mathrm{min} \mathrm{m}^{-1}$ respectively. D-glucose uptake appeared $30 \mathrm{~min}$ after glucose addition and the maximal transport rate was achieved $2 \mathrm{~h}$ later. When $\mathrm{D}$-gluconic acid was added to the cultures GTS was not induced (data not shown). 
Table 2. D-Glucose uptake of $P$. putida when incubated in the presence of different energy inhibitors

Uptake is expressed as a percentage of the uptake in the control incubation (100\%) which corresponds to $1500 \mathrm{pmol} \mathrm{min}^{-1}$. The

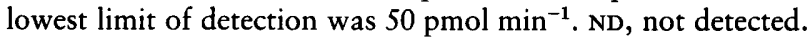
The data reported in this table are the mean of three different assays.

\begin{tabular}{|lccc|}
\hline Inhibitor & \multicolumn{3}{c|}{ Glucose uptake (\%) } \\
\cline { 2 - 4 } & $1 \mathbf{m M}^{*}$ & $\mathbf{1 0 0} \boldsymbol{\mu} \mathbf{M}^{*} \quad \mathbf{1 0} \boldsymbol{\mu} \mathbf{M}^{*}$ \\
\hline Control (none) & 100 & & \\
Potassium arsenate & 100 & & \\
2-Nitrophenol & 70 & & 52 \\
4-Nitrophenol & $\mathrm{ND}$ & 30 & \\
Sodium azide & 60 & & \\
Potassium cyanide & 12 & 70 & \\
Sodium fluoride & 97 & & \\
$N, N^{\prime}$-Dicyclohexylcarbodiimide & 100 & & \\
\hline
\end{tabular}

* Final concentration of the inhibitor in the assay.

These data are similar to those previously reported for the GTS of $P$. aeruginosa (Cuskey et al., 1985; Stinson et al., 1977). In this bacterium D-glucose is taken up by an inducible, active transport system and the $K_{\mathrm{m}}$ value is $8 \mu \mathrm{M}$ (Whiting et al., 1976b).

$\mathrm{D}$-Gluconic acid did not inhibit the transport of $\mathrm{D}$ glucose, indicating that the presence of this acid in the medium is not responsible for the lack of utilization of this sugar. We then assayed hexokinase in cell-free extracts of $P$. putida obtained when this bacterium was grown in $M M+10 \mathrm{mM}$ glucose. We found that this enzyme was present in the bacteria and therefore the lack of D-glucose utilization cannot be explained by the absence of this enzyme. These results contrast with those reported for Penicillium chrysogenum NRRL 1951 B25, a strain which accumulates D-gluconic acid and lacks hexokinase activity (Sih \& Knight, 1956). Similar results to those reported in filamentous fungi have been described for Azotobacter vinelandii (Mortenson \& Wilson, 1954) and in P. fluorescens (Wood \& Schwert, 1954).

Finally, we studied the third enzyme glucose phosphate isomerase (King, 1974). We detected only traces of this enzyme in cell-free extracts of $P$. putida U even when this bacterium was cultured in $\mathrm{MM}+10 \mathrm{mM}$ glucose. These data might explain why glucose cannot be efficiently catabolized through glycolysis. Furthermore, we assayed 6-phosphofructokinase and we were not able to find this enzyme in cell-free extracts of $P$. putida $\mathrm{U}$ grown in glucose or in fructose. The lack of this key enzyme of the Embden-Meyerhoff pathway (Conway, 1992) suggests that this bacterium does not metabolize glucose to triose phosphate via this route. Similar results have been reported in $P$. aeruginosa, $P$. doudoroffii and in other pseudomonads (Lessie \& Phibbs, 1984).
The above data suggest, that among all the possible pathways that can be used by different microbes to catabolize gluconic acid (see Fig. 1), only the pentose phosphate pathway or the Entner-Doudoroff pathway can be employed by this micro-organism. However, we observed that $P$. putida was unable to catabolize pentoses such as $\mathrm{L}$ - or D-arabinose, D-xylose and Dribose (data not shown). Similar results have been reported in different pseudomonads (Quay et al., 1972; Matsushita \& Ameyama, 1982; Duine et al., 1986; Hardy et al., 1993). Thus, P. putida and other pseudomonads can oxidize xylose via a pyrroloquinoline quinone-dependent glucose dehydrogenase, but the product xylonate cannot be metabolized. Therefore, these organisms cannot grow on xylose, but can derive energy from its oxidation (Hardy et al., 1993). In P. putida it is possible that the pentose phosphate pathway is nonfunctional although a block on pentose uptake cannot be excluded. We therefore conclude that the degradation of D-glucose via D-gluconic acid most likely follows the Entner-Doudoroff pathway, as has been reported for other micro-organisms (Lakshminarayana et al., 1969; Ornston, 1971; Elzainy et al., 1973; Vicente \& Canovas, 1973; Eisenberg et al., 1974; Whiting et al., 1976b; Lessie \& Phibbs, 1984).

From the above data it can be inferred that $P$. putida $\mathrm{U}$ is unable to catabolize D-glucose by the glycolytic pathway and that this bacterium oxidizes this sugar to gluconic acid, which is accumulated in the broth before being taken up and catabolized. This special catabolic behaviour affords this bacterium certain ecological advantages since rapid glucose oxidation prevents the sugar from being used by competitors. Thus, as a result of what was initially a metabolic requirement, $P$. putida $\mathrm{U}$ has managed to achieve a metabolic advantage that increases its survival potential in the biosphere.

\section{ACKNOWLEDGEMENTS}

We are grateful to N. S. D. Skinner for revising the English version of the manuscript and to Dr A. Cañedo for the NMR work. This investigation was supported by grants from the Comision Interministerial de Ciencia y Tecnología (CICYT), Madrid, Spain (grant no. Bio 93-1188) and the Junta de Castilla y León (Conserjería de Cultura y Turismo).

\section{REFERENCES}

Anderson, A. J. \& Dawes, E. A. (1990). Occurrence, metabolism, metabolic role, and industrial uses of bacterial polyhydroxyalkanoates. Microbial Rev 54, 450-472.

Bayly, R. C. \& Wigmore, G. J. (1973). Metabolism of phenol and cresols by mutants of Pseudomonas putida. J Bacteriol 113, 1112-1120.

Bendall, M. R., Pegg, D. l., Doddrell, D. M. \& Williams, D. H. (1982). Strategy for the generation of ${ }^{13} \mathrm{C}$ subspectra. Application to the analysis of the ${ }^{13} \mathrm{C}$ spectrum of the antibiotic ristocetin. $J$ Org Chem 47, 3021-3023.

Bergmeyer, H. U. (1974a). Fructose-6-phosphate kinase from rabbit muscle. In Methods of Enzymatic Analysis, vol. 1, p. 451. Edited by H. U. Bergmeyer. New York: Academic Press. 
Bergmeyer, H. U. (1974b). Gluconate kinase. In Methods of Enzymatic Analysis, vol. 1, pp. 457-458. Edited by H. U. Bergmeyer. New York: Academic Press.

Bergmeyer, H. U. (1974c). Hexokinase from yeast. In Methods of Enzymatic Analysis, vol. 1, pp. 473-474. Edited by H. U. Bergmeyer. New York: Academic Press.

Bock, R. \& Pedersen, C. (1983). Carbon-13 nuclear magnetic resonance spectroscopy of monosaccharides. Adv Carbohydr Chem Biochem 41, 27-28.

Bradford, M. M. (1976). A rapid and sensitive method for the quantification of microgram quantities of protein utilizing the principle of protein-dye binding. Anal Biochem 72, 248-254.

Ciucu, A. \& Patroescu, C. (1984). Fast spectrometric method of determining the activity of glucose oxidase. Anal Lett 17, 1417-1427.

Collinsworth, W. L., Chapman, P. J. \& Dagley, S. (1973). Stereospecific enzymes in the degradation of aromatic compounds by Pseudomonas putida. J Bacteriol 133, 922-931.

Conway, T. (1992). The Entner-Doudoroff pathway: history, physiology and molecular biology. FEMS Microbiol Rev 103, 1-28.

Cyskey, S. M., Wolff, J. A., Phibbs, P. V., Jr \& Olsen, R. H. (1985). Cloning of genes specifying carbohydrate catabolism in Pseudomonas aeruginosa and in Pseudomonas putida. J Bacteriol 162, 865-871.

Dagley, S. (1975). A biochemical approach to some problems of environmental pollution. Essays Biochem 11, 81-138.

Duine, J. A., Frank, J., Jzn \& Jongejan, J. A. (1986). PQQ and quinoprotein enzymes in microbial oxidations. FEMS Microbiol Rev 32, 165-178.

Dunn, N. W. \& Gunsalus, I. C. (1973). Transmissible plasmid coding early enzymes of naphthalene oxidation in Pseudomonas putida. J Bacteriol 114, 974-979.

Eisenberg, R. C., Butters, S. J., Quay, S. C. \& Friedman, S. B. (1974). Glucose uptake and phosphorylation in Pseudomonas fluorescens. J Bacteriol 120, 147-153.

Elzainy, T. A., Hassan, M. M. \& Allam, A. L. (1973). Occurrence of the non-phosphorylated pathway for gluconate degradation in different fungi. Biochem Syst Ecol 1, 127-128.

Fuchs, G., Mohamed, M., Altenschmidt, U., Köch, J., Lack, A., Brackmann, R., Lochmeyer, C. \& Oswald, B. (1994). Biochemistry of anaerobic degradation of aromatic compounds. In Biochemistry of Microbial Degradation, pp. 513-553. Edited by C. Ratledge. London: Kluwer Academic Publisher.

Galli, E., Barbieri, P. \& Bestetti, G. (1992a). Potential of Pseudomonads in the degradation of methylbenzenes. In Pseudomonas: Molecular Biology and Biotechnology, pp. 268-276. Edited by E. Galli, S. Silver \& B. Witholt. Washington, DC: American Society for Microbiology.

Galli, E., Silver, S. \& Witholt, B. (editors) (1992b). Pseudomonas : Molecular Biology and Biotechnology. Washington, DC: American Society for Microbiology.

Gibson, D. T., Hensley, M., Yoshioka, H. \& Marby, T. J. (1970). Formation of (+)-cis-2,3-dihydroxy-1-methylcyclohexa-4,6diene from toluene by Pseudomonas putida. Biochemistry 9, 1626-1630.

Hardy, G. P. M. A., Teixeira de Mattos, M. J. \& Neijssel, O. M. (1993). Energy conservation by pyrroloquinoline quinol-linked xylose oxidation in Pseudomonas putida NCTC 10936 during carbon-limited growth in chemostat culture. FEMS Microbial Lett 107, 107-110.
Hauge, J. G. (1966). Glucose dehydrogenase-particulate. Methods Enzymol 9, 92-98.

Jermyn, M. A. (1960). Studies on the glucono- $\delta$-lactonase of $P s$. fluorescens. Biochim Biophys Acta 37, 78-92.

Keston, A. S. (1956). Abstract 129. Abstracts of the 5th Meeting of the American Chemical Society, Dallas, Texas, pp. 310-314.

Kheshghi, S., Roberts, H. R. \& Bucek, W. (1954). Studies on the production of 5 -ketogluconic acid by Acetobacter suboxydans. Appl Microbiol 2, 183-190.

King, J. (1974). Glucosephosphate isomerase. In Methods of Enzymatic Analysis, vol. 2, pp. 1113-1117. Edited by H. U. Bergmeyer. New York: Academic Press.

Kobal, W. M., Gibson, D. T., Dawis, R. E. \& Garza, A. (1973). X-ray determination of the absolute stereochemistry of the initial oxidation product formed from toluene by Pseudomonas putida 39/D. J Am Chem Soc 95, 4420-4421.

Lageveen, R. G., Huisman, G. W., Preusting, H., Ketelaar, P., Eggink, G. \& Witholt, B. (1988). Formation of polyesters by Pseudomonas oleovorans: effect of substrates on formation and composition of poly-(R)-3-hydroxyalkanoates and poly-(R)-3hydroxyalkenoates. Appl Environ Microbiol 54, 2924-2932.

Lakshminarayana, K., Modi, V. V. \& Shah, V. K. (1969). Studies on gluconate metabolism in A. niger. Arch Mikrobiol 66, 389-395.

Lessie, T. G. \& Phibbs, P. V., Jr (1984). Alternative pathways of carbohydrate utilization in Pseudomonads. Annu Rev Microbiol 38, 359-387.

Lindow, S. E. (1992). Environmental release of Pseudomonads: potential benefits and risks. In Pseudomonas: Molecular Biology and Biotechnology, pp. 399-407. Edited by E. Galli, S. Silver \& B. Witholt. Washington, DC: American Society for Microbiology.

Luengo, J. M., Revilla, G., Lopez-Nieto, M. J., Villanueva, J. R. \& MartIn, J. F. (1980). Inhibition and repression of homocitrate synthase by lysine in Penicillium chrysogenum. J Bacteriol 144, 869-876.

Lunt, D. \& Evans, W. C. (1970). The microbial metabolism of biphenyl. Biochem J 118, 54.

MacGregor, C. H., Wolff, J. A., Arora, S. K., Hylemon, P. B. \& Phibbs, P. V. (1992). Catabolite repression control in Pseudomonas aeruginosa. In Pseudomonas: Molecular Biology and Biotechnology, pp. 198-206. Edited by E. Galli, S. Silver \& B. Witholt. Washington, DC: American Society for Microbiology.

Martínez-Blanco, H., Reglero, A. \& Luengo, J. M. (1990a). Carbon catabolite regulation of phenylacetyl-CoA ligase from Pseudomonas putida. Biochem Biophys Res Commun 167, 891-897.

Martínez-Blanco, H., Reglero, A., Rodríguez-Aparício, L. B. \& Luengo, J. M. (1990b). Purification and biochemical characterization of phenylacetyl-CoA ligase from Pseudomonas putida. A specific enzyme for the catabolism of phenylacetic acid. J Biol Chem 265, 7084-7090.

Matsushita, K. \& Ameyama, M. (1992). D-Glucose dehydrogenase from Pseudomonas fluorescens, membrane-bound. Methods Enzymol 89, 149-154.

Milson, P. E. \& Meers, J. L. (1985). Gluconic and itaconic acids. In Comprehensive Biotechnology, vol. 3, pp. 681-700. Edited by M. Moo Young. Oxford: Pergamon Press.

Mortenson, L. E. \& Wilson, P. W. (1954). Initial stages in the breakdown of carbohydrates by Azotobacter vinelandii. Arch Biochem Biophys 53, 425-435.

Neu, H. C. \& Heppel, L. A. (1965). The release of enzymes from Escherichia coli by osmotic shock and during the formation of spheroplasts. J Biol Chem 240, 3685-3692. 
Ornston, L. N. (1971). Regulation of catabolic pathways in Pseudomonas. Bacteriol Rev 35, 87-116.

Ortiz, A. I., Reglero, A., Rogríguez-Aparicio, L. B. \& Luengo, J. M. (1989). In vitro synthesis of colominic acid by membrane-bound sialyltransferase of Escherichia coli K-235. Kinetic properties of this enzyme and inhibition by CMP and other cytidine nucleotides. Eur J Biochem 178, 741-749.

Petruccioli, M., Fenice, M. \& Piccioni, P. (1993). Distribution and typology of glucose oxidase activity in the genus Penicillium. Lett Appl Microbiol 17, 285-288.

Quay, S. C., Friedman, S. B. \& Eisenberg, R. C. (1972). Gluconate regulation of glucose catabolism in Pseudomonas fuorescens. $J$ Bacteriol 112, 291-298.

Ramos, J. L. \& Timmis, K. N. (1987). Experimental evolution of catabolic pathways of bacteria. Microbiol Sci 4, 228-237.

Rodriguez-Aparicio, L. B., Reglero, A. \& Luengo, J. M. (1987). Uptake of $N$-acetylneuraminic acid by Escherichia coli K-235. Biochemical characterization of the transport system. Biochem J 246, 287-294.

Rodríguez-Aparicio, L. B., Reglero, A., Ortiz, A. I. \& Luengo, J. M. (1988). A protein-sialyl polymer complex involved in colominic acid biosynthesis. Biochem J 251, 589-596.

Schleissner, C., Olivera, E. R., Fernández-Valverde, M. \& Luengo, J. M. (1994). Aerobic catabolism of phenylacetic acid in Pseudomonas putida $\mathrm{U}$ : biochemical characterization of a specific phenylacetic acid transport system and formal demonstration that phenylacetyl-Coenzyme $\mathrm{A}$ is a catabolic intermediate. J Bacteriol 176, 7667-7676.

Sih, C. J. \& Knight, S. G. (1956). Carbohydrate metabolism of Penicillium chrysogenum. J Bacteriol 72, 694-699.

Steinbuchel, A., Kruger, N., Valentin, H., Timm, A., Pries, A., Hustede, E. \& Schegel, H. G. (1992). Physiological and genetic analysis of polyhydroxyalkanoate biosynthetic pathways. In Pseudomonas: Molecular Biology and Biotechnology, pp. 315327. Edited by E. Galli, S. Silver \& B. Witholt. Washington, DC: American Society for Microbiology.

Stinson, M. W., Cohen, M. A. \& Merrick, J. M. (1977). Purification and properties of the periplasmic glucose-binding protein of Pseudomonas aeruginosa. J Bacteriol 131, 672-681.
Strecker, H. J. (1955). Glucose dehydrogenase from liver. Methods Enzymol 1, 335-339.

Stubbs, J. J., Lockwood, L. B., Roe, E. T., Tabenkin, B. \& Ward, G. E. (1940). Ketogluconic acids from glucose. Ind Eng Chem 32, 1626-1630.

Troy, F. A., Vijay, I. K., McCloskey, M. A. \& Rohr, T. E. (1982). Synthesis of capsular polymers containing polysialic acid in Escherichia coli O7-K1. Methods Enzymol 83, 540-548.

Tsai, C. S., Ye, H. G. \& Sni, J. L. (1995). Carbon-13 NMR studies and purification of gluconate pathway enzymes from Schizosaccharomyces pombe. Arch Biochem Biophys 316, 155-162.

Van Dijken, J. P. \& Veenhuis, M. (1980). Cytochemical localization of glucose oxidase in peroxisomes of A. niger. Eur J Appl Microbiol Biotechnol 9, 275-283.

Vicente, M. \& Canovas, J. L. (1973). Glycolysis in Pseudomonas putida: physiological role of alternative routes from the analysis of defective mutants. $J$ Bacteriol 116, 908-914.

Whiting, P. H., Midgley, M. \& Dawes, E. A. (1976a). The role of glucose limitation in the regulation of the transport of glucose, gluconate and 2-oxogluconate, and of glucose metabolism in Pseudomonas aeruginosa. J Gen Microbiol 92, 304-310.

Whiting, P. H., Midgley, M. \& Dawes, E. A. (1976b). The regulation of transport of glucose, gluconate and 2-oxogluconate and of glucose catabolism in Pseudomonas aeruginosa. Biochem $J 154,659-668$.

Witteveen, C. F. B., van de Vordervoort, P., Swart, K. \& Visser, J. (1990). Glucose oxidase overproducing and negative mutants of Aspergillus nidulans Appl Environ Microbiol 33, 683-686.

Wood, W. A. \& Schwert, R. F. (1953). Carbohydrate oxidation by Ps. fluorescens. J Biol Chem 201, 501-511.

Wood, W. A. \& Schwert, R. F. (1954). Carbohydrate oxidation by Pseudomonas fluorescens. II. Mechanism of hexose phosphate oxidation. J Biol Chem 206, 625-635.

Received 5 August 1996; revised 12 December 1996; accepted 2 January 1997. 